\title{
Wide Distribution and Diversity of Malaria-Related Haemosporidian Parasites (Polychromophilus spp.) in Bats and Their Ectoparasites in Eastern Europe
}

\author{
Attila D. Sándor ${ }^{1,2, *,+} \mathbb{0}$, Áron Péter ${ }^{1,+} \mathbb{D}^{\mathbb{D}}$, Alexandra Corduneanu ${ }^{1,+}$, Levente Barti ${ }^{1,3}$, István Csósz $^{3}$, \\ Zsuzsa Kalmár ${ }^{1}$, Sándor Hornok ${ }^{2}$, Jenó Kontschán ${ }^{4}$ and Andrei D. Mihalca ${ }^{1}$ \\ 1 Department of Parasitology and Parasitic Diseases, Faculty of Veterinary Medicine, University of Agricultural \\ Sciences and Veterinary Medicine of Cluj-Napoca, RO-400036 Cluj Napoca, Romania; \\ aronpeter92@gmail.com (Á.P.); alexandra.corduneanu@usamvcluj.ro (A.C.); bartilev@yahoo.com (L.B.); \\ zsuzsa.kalmar@usamvcluj.ro (Z.K.); amihalca@usamvcluj.ro (A.D.M.) \\ 2 Department of Parasitology and Zoology, University of Veterinary Medicine, H-1078 Budapest, Hungary; \\ hornok.sandor@univet.hu \\ 3 Myotis Bat Conservation Group, RO-530171 Miercurea Ciuc, Romania; styepan@freemail.hu \\ 4 Centre for Agricultural Research, Plant Protection Institute, ELKH, H-1022 Budapest, Hungary; \\ jkontschan@gmail.com \\ * Correspondence: attila.sandor@usamvcluj.ro; Tel.: +40-740-499146 \\ + Authors contributed equally.
}

check for updates

Citation: Sándor, A.D.; Péter, Á.; Corduneanu, A.; Barti, L.; Csősz, I.; Kalmár, Z.; Hornok, S.; Kontschán, J.; Mihalca, A.D. Wide Distribution and Diversity of Malaria-Related Haemosporidian Parasites (Polychromophilus spp.) in Bats and Their Ectoparasites in Eastern Europe. Microorganisms 2021, 9, 230. https: / / doi.org/10.3390/ microorganisms 9020230

Received: 22 December 2020

Accepted: 20 January 2021

Published: 22 January 2021

Publisher's Note: MDPI stays neutral with regard to jurisdictional claims in published maps and institutional affiliations.

Copyright: (C) 2021 by the authors. Licensee MDPI, Basel, Switzerland. This article is an open access article distributed under the terms and conditions of the Creative Commons Attribution (CC BY) license (https:/ / creativecommons.org/licenses/by/ $4.0 /)$.

\begin{abstract}
Malaria is responsible for major diseases of humans, while associated haemosporidians are important factors in regulating wildlife populations. Polychromophilus, a haemosporidian parasite of bats, is phylogenetically close to human-pathogenic Plasmodium species, and their study may provide further clues for understanding the evolutionary relationships between vertebrates and malarial parasites. Our aim was to investigate the distribution of Polychromophilus spp. in Eastern Europe and test the importance of host ecology and roost site on haemosporidian parasite infection of bats. We sampled bats and their ectoparasites at eight locations in Romania and Bulgaria. DNA was extracted from blood samples and ectoparasites and tested individually for the presence of DNA of Polychromophilus spp. using a nested PCR targeting a $705 \mathrm{bp}$ fragment of cytB. Two species of Polychromophilus were identified: Po. melanipherus in Miniopterus schreibersii and associated ectoparasites and Po. murinus in rhinolophid and vespertilionid bats (6 species) and their ticks and nycteribiid flies. Only cave-dwelling bat species (and their ectoparasites) showed infections, and we found a strong correlation between infections with Polychromophilus parasites and Nycteribiidae prevalence. We report the high genetic diversity of Polychromophilus spp. in Eastern Europe, suggesting that the simultaneous presence of varied host and vector assemblages enhances bat haemosporidian parasite diversity.
\end{abstract}

Keywords: Chiroptera; Ixodidae; Nycteribiidae; pathogens; Plasmodiidae

\section{Introduction}

Haemosporidians causing malaria are responsible for major diseases of humans (e.g., malarial infections in humans resulted in an estimated 228 million cases and 405,000 deaths in 2018 [1]). Certain species also act as important factors in regulating wildlife populations. The impact of malaria parasites was considered crucial in the extinction of Maclear's rat (Rattus macleari) on Christmas Island [2], and it should be blamed for the extinction of up to 23 endemic Hawaiian bird species [3]. Recently avian malaria parasites were suggested to be the cause of the widespread decline of house sparrows (Passer domesticus) in Europe [4]. Host switching was recorded for several haemosporidian parasites [5,6], with even the most pathogenic human malaria species, Plasmodium falciparum, being suggested as a recent pathogen with a chimpanzee origin [7]. Other malaria-like haemosporidian parasites 
occurring in wildlife (e.g., Polychromophilus species of bats) are phylogenetically close to human-pathogenic Plasmodium species [8-10]; thus, their study may provide further clues in our fight against humanity's most deadly infectious disease [11].

Bats are suggested or demonstrated reservoirs for a large variety of pathogens causing emerging infectious diseases such as viruses [12], bacteria [13], and protozoa [14-16]. The study of Hemosporidia [17] of bats can further provide an in-depth understanding of the evolutionary relationships between vertebrates and malarial parasites $[6,18,19]$, especially in the view of the remarkable natural tolerance of bats towards these parasites [20,21].

Nine genera of Plasmodiidae infect bats worldwide: Biguetiella, Bioccala, Dionisia, Hepatocystis, Johnsprentia, Nycteria, Plasmodium, Polychromophilus, and Sprattiella [22] and based on current data; only Polychromophilus is present in Europe [6]. The genus Polychromophilus includes five species globally (Po. adami, Po. corradetii, Po. deanei, Po. melanipherus and Po. murinus), with two species infecting different hosts groups in Europe: Po. melanipherus is a parasite of the long-winged bat (Miniopterus schreibersii), while Po. murinus occurs mainly in vesper bats (Vespertilionidae) and certain rhinolophid species [23]. Unlike in other hosts, seemingly bats show little or no physiological symptoms associated with Polychromophilus infections [20].

The presence of Polychromophilus spp. are known in Europe from Great Britain, Italy, the Netherlands, and Switzerland [23-26]. However, to the best of our knowledge, there are no reports on malaria-related haemosporidian parasites of bats in the eastern part of the continent. As with most haemosporidians, Polychromophilus spp. are vector-borne parasites, with arthropod ectoparasites suggested to biologically transfer sporozoites between bats [27]. Bat flies (Diptera: Nycteribiidae) were suspected to be the main vectors of Polychromophilus spp. $[27,28]$. Thus, we hypothesize that bat species frequently infected by bat flies will show a higher prevalence of Polychromophilus spp. infections. In this context, our aims were to: (a) investigate the distribution of Polychromophilus spp. in Eastern Europe by sampling a diverse range of bat species, and (b) test whether there are differences in Polychromophilus spp. infection between primarily cave-dwelling (roosting in large underground shelters and commonly parasitized by bat flies) and crevice-roosting bat species (usually roosting in tree holes or crevices in built environments and rarely hosting bat flies). We predict that bat species resident in caves should show higher Polychromophilus spp. infection rates, than crevice-dwelling bat species. We also screened different ectoparasites collected from Polychromophilus-positive bats in order to establish their possible carrier role for haemosporidian parasites.

\section{Materials and Methods}

Blood samples were collected from live caught bats at eight different locations in Romania and Bulgaria (Figure 1, Table 1) in the spring and autumn of 2017 and 2018. For capturing the bats, mist nets and harp traps were set close to the entrances of roosts or in suitable habitat patches. Bats were identified morphologically [29], and species, sex, age, forearm length and body weight were recorded for each individual. Blood was collected from randomly allocated (using a preset list of random numbers generated by the RandBetween function of Excel), apparently healthy individuals using venipuncture. Each bat was immobilized, the uropatagium was disinfected with alcohol, and a puncture of the uropatagial vein was made using a small needle. The drop of blood was collected on a small piece of filter paper and kept in a sterile tube. Each tube was individually marked and stored at $4{ }^{\circ} \mathrm{C}$ until DNA extraction. Bat ectoparasites were also collected from bats and preserved in 70\% ethanol in separate tubes (one tube/ectoparasite type/bat host). Identification of bat ectoparasites was based on morphological characteristics [30,31]. To assess the potential importance of host species ecology on Polychromophilus parasite prevalence, we assigned each bat species to one group (underground vs. crevice-roosting, see Table 1), according to published records [29]. 


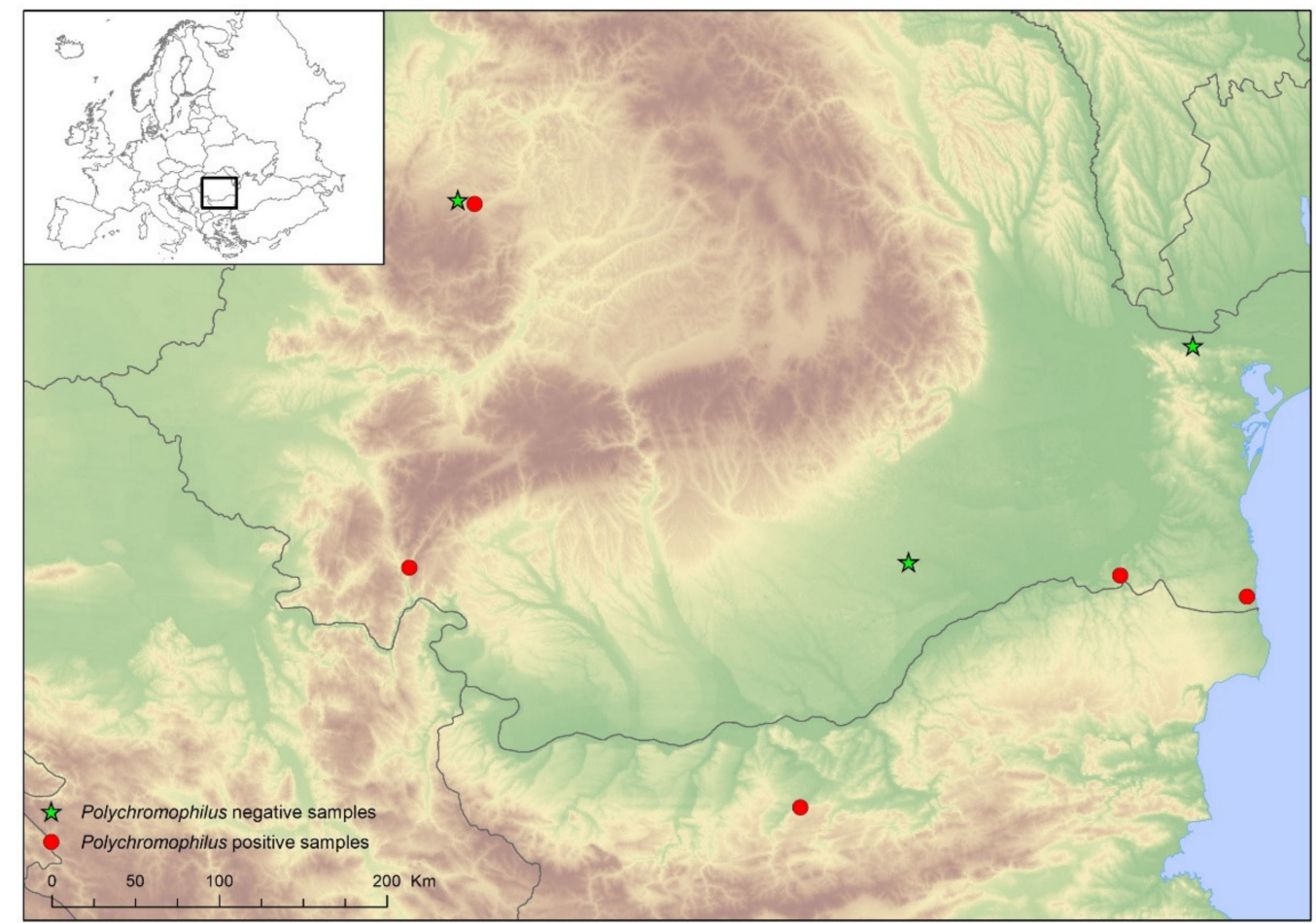

Figure 1. Geographical distribution of sampling locations used for testing Polycromophilus spp. presence in bats.

Table 1. Species and numbers of bats sampled, with roost-type, geographical locations and sample sizes (Roost type: Ccrevice roosting, U—underground shelters. Sampling locations: A-Bucharest; B-Canaraua Fetii; C-Gilău; D-Căpușu Mic; E-Limanu Cave; F-Mandrata Cave (Bulgaria); G—Băile Herculane; H-Telita).

\begin{tabular}{|c|c|c|c|c|c|c|c|c|c|c|c|c|}
\hline \multirow{2}{*}{ Bat Species } & \multirow{2}{*}{$\begin{array}{l}\text { Roost } \\
\text { Type }\end{array}$} & \multicolumn{8}{|c|}{ Locations } & \multirow[t]{2}{*}{ Total } & \multirow{2}{*}{$\begin{array}{c}\text { No Positive } \\
(\%)\end{array}$} & \multirow{2}{*}{$\begin{array}{c}\text { Polychromophilus } \\
\text { spp. }\end{array}$} \\
\hline & & $\mathbf{A}$ & B & $\mathrm{C}$ & D & $\mathrm{E}$ & $F$ & G & $\mathbf{H}$ & & & \\
\hline Eptesicus serotinus & $\mathrm{C}$ & & 1 & & & & & & & 1 & & \\
\hline Miniopterus schreibersii & $\mathrm{U}$ & & 46 & & & & & & & 46 & $31(67.4)$ & Po. melanipherus \\
\hline Myotis alcathoe & $\mathrm{C}$ & & & & 4 & & & & & 4 & & \\
\hline Myotis blythii & $\mathrm{U}$ & & 6 & 3 & & & & 1 & & 10 & $1(10.0)$ & Po. murinus \\
\hline Myotis capaccinii & $\mathrm{U}$ & & & & & & & 1 & & 1 & & \\
\hline Myotis daubentonii & $\mathrm{U}$ & & 1 & & & 15 & & & & 16 & $9(56.2)$ & Po. murinus \\
\hline Myotis emarginatus & $\mathrm{C}$ & & & 10 & & & & & & 10 & & \\
\hline Myotis myotis & $\mathrm{U}$ & & & 1 & & & 5 & 2 & & 8 & $6(75)$ & Po. murinus \\
\hline Myotis nattereri & $\mathrm{C}$ & & 12 & & & & & & & 12 & & \\
\hline Nyctalus lasiopterus & $\mathrm{C}$ & & 1 & & & & & & & 1 & & \\
\hline Nyctalus noctula & $\mathrm{C}$ & 95 & 39 & & & & & & & 134 & & \\
\hline Pipistrellus kuhlii & $\mathrm{C}$ & 2 & & & & & & & & 2 & & \\
\hline Pipistrellus nathusii & $\mathrm{C}$ & & 5 & & & & & & & 5 & & \\
\hline Plecotus austriacus & $\mathrm{C}$ & & & & & & & & 1 & 1 & & \\
\hline $\begin{array}{l}\text { Rhinolophus } \\
\text { ferrumequinum }\end{array}$ & $\mathrm{U}$ & & & 9 & & & & & & 9 & $1(11.11)$ & Po. murinus \\
\hline Rhinolophus hipposideros & $\mathrm{U}$ & & & & & 2 & & & & 2 & $1(50)$ & Po. murinus \\
\hline Rhinolophus mehelyi & $\mathrm{U}$ & & & & & 2 & & & & 2 & $1(50)$ & Po. murinus \\
\hline Vespertilio murinus & $\mathrm{C}$ & 1 & 4 & & & & & & & 5 & & \\
\hline Total & & 98 & 115 & 23 & 4 & 19 & 5 & 5 & 1 & 270 & & \\
\hline
\end{tabular}

Ectoparasites of bats with Polychromophilus-positive blood samples were selected and grouped in pools according to their species, host, developmental stage (for ticks only), and sex for DNA extraction. Ticks and bat flies were tested individually (24) or in pools 
(11 pools, 2-3 flies belonging to the same species and sex collected from the same host), with Polychromophilus spp. Genomic DNA was extracted from the blood from filter papers using an Isolate II Genomic DNA kit (Bioline, London, UK). The genomic DNA of bat ectoparasites was extracted using the QIAamp DNA Mini Kit (Qiagen, Hilden, Germany) according to the manufacturer's instructions. All the DNA samples were stored at $-20{ }^{\circ} \mathrm{C}$ until further analysis.

A nested PCR targeting a $705 \mathrm{bp}$ fragment of $c y t \mathrm{~B}$ gene using previously described primers [6] was used for screening. The reactions were carried out as follows: $25 \mu \mathrm{L}$ reaction mixture containing $12.5 \mu \mathrm{L}$ Master Mix (My Taq ${ }^{\mathrm{TM}}$ Red Mix, Bioline, London, UK), $7.5 \mu \mathrm{L}$ water, $1 \mu \mathrm{L}$ of each primer $(10 \mathrm{pmol} / \mu \mathrm{L})$ and $3 \mu \mathrm{L}$ aliquot of isolated DNA in the first round and in the second round instead of DNA $1 \mu \mathrm{L}$ of PCR product from the first reaction was used. The PCR was performed using the T1000 ${ }^{\mathrm{TM}}$ thermal cycler (Bio-Rad, London, $\mathrm{UK}$ ) with the following condition: initial denaturation at $94{ }^{\circ} \mathrm{C}$ for $5 \mathrm{~min}$, then 25 cycles (for the first reaction) and 35 cycles (for the second reaction) of denaturation at $94{ }^{\circ} \mathrm{C}$ for $30 \mathrm{~s}$, annealing at $47.2^{\circ} \mathrm{C}$ for $30 \mathrm{~s}$ (for both reactions), and extension at $72{ }^{\circ} \mathrm{C}$ for $45 \mathrm{~s}$ and a final extension at $72{ }^{\circ} \mathrm{C}$ for $10 \mathrm{~min}$. For each set of reactions (45 samples) 2 negative controls (distilled water) and one positive control, which was Polychromophilus spp.-positive DNA isolated from bat flies of Common bent-wing bat (Mi. schreibersii) collected from Italy were included.

Amplification products were visualized by electrophoresis on $1.5 \%$ agarose gel stained with RedSafe ${ }^{\mathrm{TM}}$ 20,000 $\times$ nucleic acid staining solution (Chembio, Rickmansworth, UK), and their molecular weight was assessed by comparison to a molecular marker $100 \mathrm{bp}$ DNA Ladder (O'GeneRuler TM, Thermo Fisher Scientific, Waltham, MA, USA). PCR products were purified and sequenced (Macrogen Europe, Amsterdam, Netherlands). Obtained sequences were manually edited, then aligned and compared to those available in GenBank ${ }^{\mathrm{TM}}$ by basic local alignments tool (BLAST) analysis. The MEGA model selection method was applied to choose the appropriate model for phylogenetic analyses. In the phylogenetic analyses, reference sequences with high coverage (i.e., 99-100\% of the region amplified here) were retrieved from GenBank and trimmed to the same length. Phylogenetic analyses were conducted by MEGA version 7.0 using the maximum-likelihood method, HasegawaKishino-Yano (HKY) model according to the selection of the program and 1000 bootstraps. The sequences were deposited in GenBank under the following accession numbers (Po. melanipherus: MT996236, MT996237, MT996238, MT996239, MT996240, MT996241, MT996242, MT996243; Po. murinus: MT996244, MT996245, MT996246, MT996247, MT996248).

\section{Results}

Blood samples were taken from a total of 270 bats belonging to 19 species (Table 1 , Figure 1). Among these bats, 59 individuals had ectoparasites, which were also included in the analysis. The DNA of Polychromophilus spp. was identified in the blood samples of 50 bats (general prevalence was 18.5\%, CI: 14.3-23.5\%), belonging to 7 species. In the case of positive samples, prevalence showed wide variations among different species, ranging from $10 \%$ (Myotis blythii) to $67.3 \%$ (Mi. schreibersii), or even $75 \%$ (My. myotis; see also Table 1). Sequencing showed the presence of two Polychromophilus spp. (Figures 2 and 3). The samples from Mi. schreibersii showed a 99-100\% identity to Po. melanipherus from Central and Southern Europe (Switzerland and Italy), but also showed an identity of 97.7-98.5\% with Po. melanipherus collected from Mi. gleni in Madagascar. Blood samples from rhinolophid and vespertilionid bats all hosted different sequences of Po. murinus, with a sequence identity of $96.3-99.8 \%$ to reference sequences from bats (My. daubentonii, My. myotis) sampled in Switzerland and deposited in GenBank ${ }^{\mathrm{TM}}$ (Figure 2).

Ectoparasites were collected at three locations (Băile Herculane, Canaraua Fetii and Limanu Cave, all in Romania). Two bat species were infested with ticks (prevalence $54.2 \%$, mean intensity 4.2 tick/host, Tables 2 and 3): Mi. schreibersii carried Ixodes simplex (prevalence $78.9 \%$, mean intensity 4.4), while My. daubentonii was infected by I. vespertilionis (prevalence 11.8\%, mean intensity 2.0, for other details, see Sándor et al. 2019 [32]). Bat flies 
( $n=53$, seven species, mean prevalence $11.1 \%$ ) were collected from five host species, among which the highest prevalence and diversity was recorded in the case of Mi. schreibersii (Table 2).

Table 2. Ticks found on bats, with host species, parasite life stages and presence of Polychromophilus spp. DNA in ticks.

\begin{tabular}{cccccccccc}
\hline Host Species & No Samples & \multicolumn{3}{c}{ I. simplex } & \multicolumn{2}{c}{ I. vespertilionis } & \multicolumn{3}{c}{ Polychromophilus spp. } \\
& (Infested) & F & N & L & F & N & L & Total & Positive \\
\hline Miniopterus schreibersii & $30(6)$ & 1 & 48 & 37 & - & - & - & 86 & $16 \mathrm{~L}, 10 \mathrm{~N}$ \\
Myotis daubentonii & $3(2)$ & - & - & - & - & 1 & 3 & 4 & $2 \mathrm{~L}, 1 \mathrm{~N}$ \\
\hline Total & $33(8)$ & 1 & 48 & 37 & - & 1 & 3 & 90 & $29(29.2 \%)$ \\
\hline
\end{tabular}

F-female, $\mathrm{N}$-nymph, L-larva.

Altogether, 33 tick samples (10 individuals and 23 pools) were tested for Plasmodiidae DNA, and six I. simplex pools (8.9\%) and three individuals of I. vespertilionis (one individual and one pool, 66.6\%) were positive for Polychromophilus spp. (Table 2). Three of the positive pools of I. simplex contained larvae (2,3, and 12, respectively), and further three consisted of three nymphs, collected from five different Mi. schreibersii individuals. The positive I. vespertilionis pool was made from two larvae. All these ectoparasites originated from bats that tested positive for Polychromophilus spp. However, only $20 \%$ of all DNA samples of ticks collected from Polychromophilus-positive bats were PCR-positive. The species identified with sequencing was Po. melanipherus (99.5-100\% identity with KJ131274.1) in I. simplex pools, while I. vespertilionis harbored Po. murinus (99.2\% identity with HM055588.1). Interestingly, corresponding sequences between ticks and their host individual did not show $100 \%$ sequence identity in each of the cases, with just a $94.9 \%$ identity between a 3 larva pool and the collecting host (32 linked single-nucleotide polymorphism-SNP difference, 23 deletions and 9 substitutions, 598/630 bp, see also Figure 2).

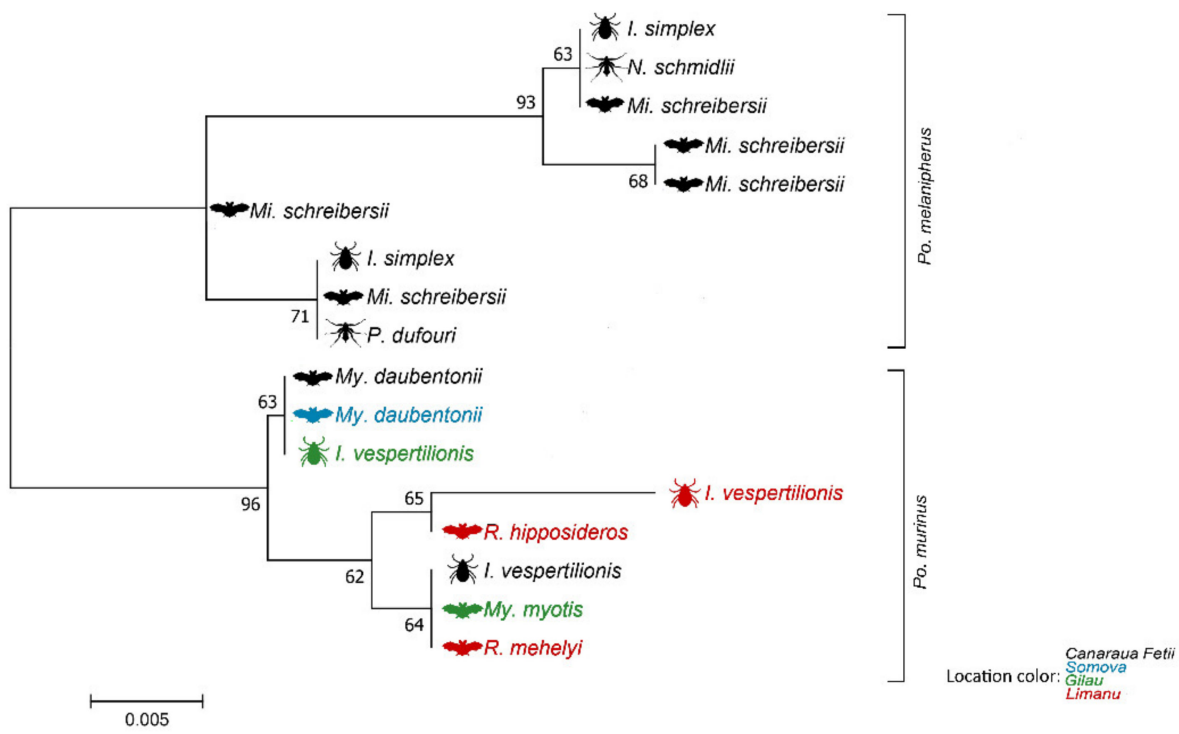

Figure 2. Un-rooted tree representing phylogenetic relationships between Polycromophilus spp. sequences collected from bats and their ectoparasites (Ixodidae and Nycteribiidae) in SE Europe. Color indicates sampling site, while symbols indicate organism type sampled (bats, bat flies and ticks). The scale-bar indicates the number of substitutions per site.

DNA of Polychromophilus spp. was detected in 23 fly samples (prevalence: 62.1\%). Five different fly species contained the DNA of haemosporidians, with high prevalence rates recorded in Penicillidia conspicua (8/11, Table 3). No infection was found in N. latreillii $(\mathrm{n}=3)$ and N. pedicularia $(\mathrm{n}=3)$. Both species of Polychromophilus spp. were identified in bat flies. In particular, flies collected from Mi. schreibersii (N. schmidlii, Pe. conspicua and Pe. 
dufourii) contained the DNA of Po. melanipherus, while flies collected from vespertilionids (N. kolenatii, N. vexata and Pe. dufourii) all tested positive for Po. murinus. These are the first records of Polychromophilus spp. identified in nycteribiid flies in Eastern Europe (Romania), with first-ever records of Po. melanipherus in Pe. conspicua and Pe. dufourii, and the first-ever records of Po. murinus in N. vexata and Pe. dufourii. DNA of Po. melanipherus was found in Pe. dufourii, collected from Mi. schreibersii (Canarau Fetii), while individuals of the same dipteran species (collected from My. blythii and My. myotis at two different sites) tested positive for Po. murinus.

Table 3. Bat flies (Nycteribiidae) analyzed for Polychromophilus spp. infection, with host species and haemosporidian species recorded.

\begin{tabular}{|c|c|c|c|c|c|c|c|}
\hline $\begin{array}{c}\text { Nycteribiidae/Host } \\
\text { Species }\end{array}$ & $\begin{array}{c}\text { Bat Fly } \\
\text { Sex }\end{array}$ & $\begin{array}{l}\text { Miniopterus } \\
\text { schreibersii }\end{array}$ & $\begin{array}{l}\text { Myotis } \\
\text { blythii }\end{array}$ & $\begin{array}{c}\text { Myotis } \\
\text { capaccinii }\end{array}$ & $\begin{array}{c}\text { Myotis } \\
\text { daubentonii }\end{array}$ & $\begin{array}{l}\text { Myotis } \\
\text { myotis }\end{array}$ & $\begin{array}{l}\text { No. of Positive Pools } \\
\text { (Detected Species) }\end{array}$ \\
\hline \multirow{2}{*}{ Nycteribia kolenatii } & $\mathrm{F}$ & & & & 1 & & 1 (Po. murinus) \\
\hline & M & & & & & & - \\
\hline \multirow{2}{*}{ Nycteribia latreillii } & $\mathrm{F}$ & & 2 & & & & - \\
\hline & M & & 1 & & & & - \\
\hline \multirow{2}{*}{ Nycteribia pedicularia } & $\mathrm{F}$ & & & 1 & & & - \\
\hline & $\mathrm{M}$ & & & 2 & & & - \\
\hline \multirow{2}{*}{ Nycteribia schmidlii } & $\mathrm{F}$ & 9 & & & & & 4 (Po. melanipherus) \\
\hline & M & 16 & & & & & 3 (Po. melanipherus) \\
\hline \multirow{2}{*}{ Nycteribia vexata } & $\mathrm{F}$ & & & & & & - \\
\hline & M & & 1 & & & & 1 (Po. murinus) \\
\hline \multirow{2}{*}{ Penicillidia conspicua } & $\mathrm{F}$ & 7 & & & & & 4 (Po. melanipherus) \\
\hline & M & 4 & & & & & 3 (Po. melanipherus) \\
\hline \multirow{2}{*}{ Penicillidia dufourii } & $\mathrm{F}$ & & & 1 & & 2 & 2 (Po. murinus) \\
\hline & M & 3 & 2 & 1 & & 3 & $\begin{array}{c}1 \text { (Po. melanipherus) } \\
4 \text { (Po. murinus) }\end{array}$ \\
\hline Total & & 39 & 6 & 5 & 1 & 5 & \\
\hline
\end{tabular}

We found high sequence diversity of both Polychromophilus spp. identified (Figure 2). Altogether six different haplotype groups differing in at least 5 SNPs were identified among sequences belonging to Po. melanipherus (highest difference between two sequences was $5.3 \%, 38$ SNP, 12 substitutions and 26 deletions, 626/664 bp), while four haplotype groups were identified among different sequences of Po. murinus (highest difference between two Po. murinus sequences was 3.9\%, 25 base pairs, 8 substitutions and 17 deletions, 615/640 bp), while highest identity was 100\% (700/702 bp). We found no geographical structuring in haplotype diversity. High identity sequences (99.99-100\%) were found at geographically distant locations (e.g., Mandrata Cave, Somova and Gilău, ca. 400 km distance either direction), while single sites held high haplogroup diversity (in case of Po. melanipherus, all six haplogroups were located at Canaraua Fetii, while three out of four haplogroups of Po. murinus were identified at Limanu).

DNA of Polychromophilus spp. was identified only in cave-dwelling bat species (Table 1) and showed a strong correlation with Nycteribiidae prevalence on host species (Pearson Rank Correlation, $\mathrm{R}_{(17)}=0.9406, p<0.001$ ). We found no statistically significant effect of neither bat sex nor age or bat fly sex on Polychromophilus spp. prevalence. Capture season had no effect on prevalence or haplotype diversity. 

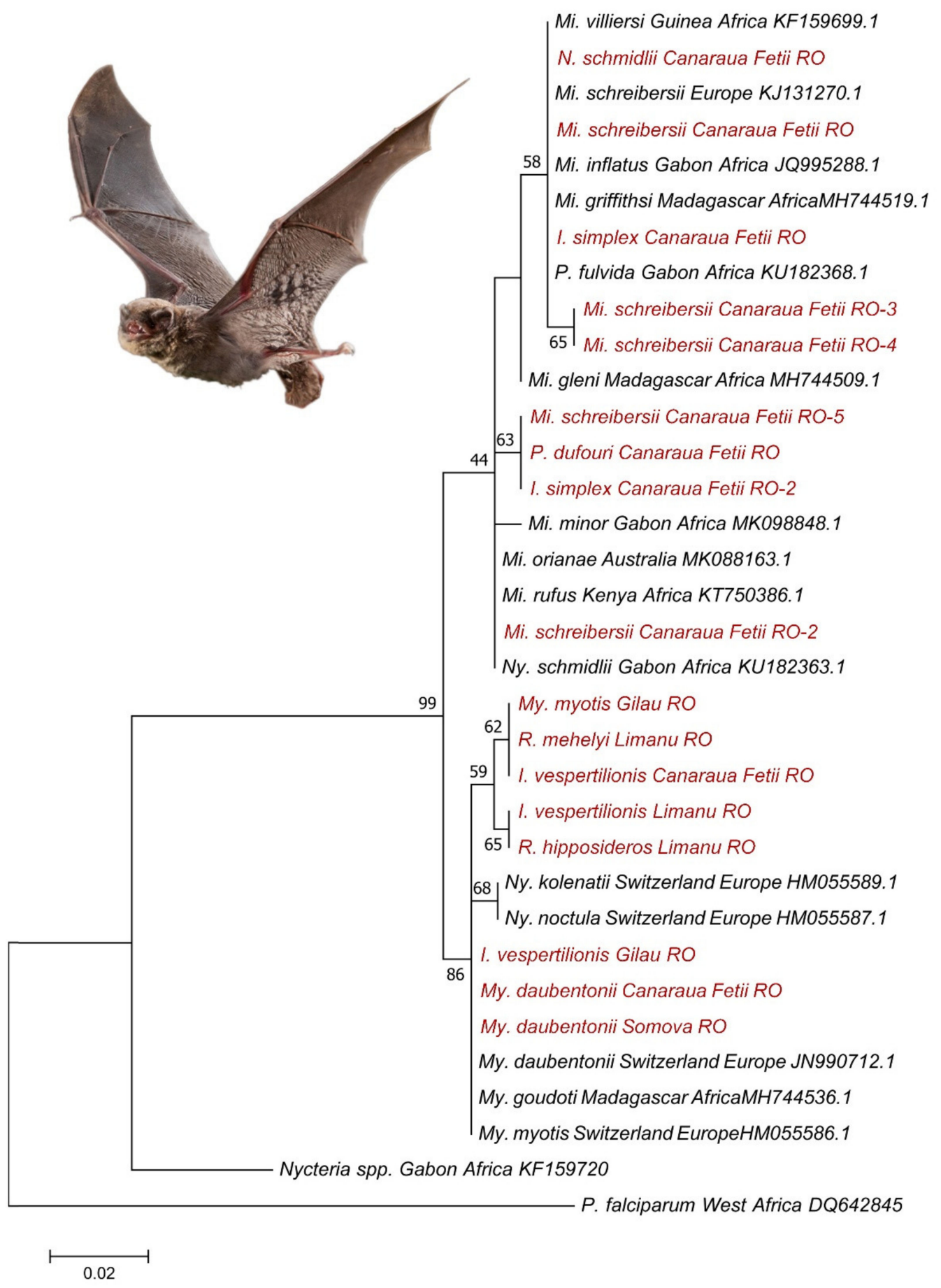

Mi. villiersi Guinea Africa KF159699.1

N. schmidlii Canaraua Fetii RO

Mi. schreibersii Europe KJ131270.1

Mi. schreibersii Canaraua Fetii RO

58 Mi. inflatus Gabon Africa JQ995288.1

Mi. griffithsi Madagascar AfricaMH744519.1

1. simplex Canaraua Fetii $R O$

P. fulvida Gabon Africa KU182368.1

Mi. schreibersii Canaraua Fetii RO-3

65 Mi. schreibersii Canaraua Fetii RO-4

Mi. gleni Madagascar Africa MH744509.1

Mi. schreibersii Canaraua Fetii RO-5

duri Canaraua Fetii RO

Mi. orianae Australia MK088163.1

Mi. rufus Kenya Africa KT750386.1

Mi. schreibersii Canaraua Fetii RO-2 
wide geographical distribution of both species of Polychromophilus in Europe after they were reported from the central, southern and western parts of the continent $[23-26,33,34]$.

With regard to host specificity of malaria-like parasites in bats, in our study Po. melanipherus was reported only from the common bent-wing bat (Mi. schreibersii), while Po. murinus had a wider host range. Polychromophilus melanipherus is a fairly common parasite of the genus Miniopterus worldwide, with at least 20 different species of bent-winged bats recorded as hosts in Europe, Africa and Australia (Table S1). While other bat species (belonging to Hipposideridae, Pteropodidae and Vespertilionidae) were recorded as hosts of Po. melanipherus in Africa and Australia, all European records of Po. melanipherus relate to Mi. schreibersii (Table S1 and references therein).

Polychromophilus murinus is the type species of the genus [35], originally being described from the particolored bat (Vespertilio murinus) and later recorded in at least six other European bat species (Myotis daubentonii, My. myotis, My. mystacinus, My. nattereri, Eptesicus serotinus, and Nyctalus noctula) (Table S1). Here we report Po. murinus DNA in three new bat hosts, with the first records listed for My. blythii, Rhinolophus hipposideros and R. mehelyi. We also reconfirmed the presence of Po. murinus in three bat species (My. daubentonii, My. myotis and R. ferrumequinum) [19,23,27,36,37]. Five species were previously shown to harbor Polychromophilus spp. tested negative in our study. While several of these species were sampled in small numbers $(\mathrm{n}=1-12)$, in the case of $N$. noctula, the sample size was relatively large $(n=134)$ from two different locations. Thus, our results indicate a low probability of infection for this bat species, at least in the investigated geographical territory.

A high prevalence of infection with Polychromophilus spp. was recorded in three bat species here, with values exceeding previous European records [19,23,27,36,37]. The mean prevalence for Po. melanipherus was $67.3 \%$ in Mi. schreibersii, while Po. murinus had a mean prevalence of $56.2 \%$ in the case of My. daubentonii and an even higher level (75\%) in My. myotis. Moreover, these prevalence rates were recorded at more than one site, thus suggesting a widespread presence of Polychromophilus spp. in these bat species.

Only $20 \%$ of ticks collected from bats in this study were found to contain the DNA of either of the two Polychromophilus species, with 8 out of the 33 tick individuals/pools testing positive (Table 2). Both positive pools of $I$. vespertilionis came from Daubenton's bat (My. daubentonii). However, the six positive pools of I. simplex (prevalence 19.3\%, Table 2) came from several different hosts. While all these ticks were collected from hosts (thus probably consumed host-blood and may show host-derived Polychromophilus DNA), their vectorial role cannot be excluded and warrant further research. Interestingly, corresponding sequence pairs (ticks and their respective bat-host individual) did not show 100\% identity in two of the cases recorded in this study (Figure 2). Either more than one Polychromophilus spp. geno-sequence was present in the sampled individuals (with nPCR being able to identify only one, an expected caveat of the methodology [38]) or ticks still maintained Polychromophilus DNA fragments from a previous meal (and host, in case of nymphs), not an unusual property of ixodid ticks [39]. To establish the vectorial role of ectoparasites, one should prove that haemosporidian parasites are able to finish their cycle inside the ectoparasite individual [40].

Altogether five different bat fly species hosted haemosporidian DNA, and one of them (Pe. dufourii) tested positive for both Polychromophilus species. Here we report the first-ever records of Po. melanipherus in Pe. conspicua and Pe. dufourii and the first-ever records of Po. murinus in N. vexata and Pe. dufourii. Nycteribiid bat flies were proposed to be the main vectors of Polychromophilus spp. in bats [27,36]. While no experimental proof has yet been published, their ubiquitous presence on bats, coupled with the high prevalence of Polychromophilus spp. recorded in bat flies themselves $[20,33,34]$ suggest this. Our results indirectly support this hypothesis. We identified a significantly higher prevalence of Polychromophilus DNA in cave-dwelling bat species known to regularly host bat flies in high abundance in Romania (Mi. schreibersii, My. blythii, My. daubentonii or My. myotis see [41]). Bat species with low levels of fly parasitism or rarely hosting nycteribiids 
(e.g., R. ferrumequinum) had low Polychromophilus DNA prevalence or tested negative for this parasite (E. serotinus, My. emarginatus, N. noctula, V. murinus, [41]).

Nycteribiid-related Po. melanipherus sequences clustered with bat-related Po. melanipherus sequences from Central and Southern Europe (99.3-100\% identity, [33]) and from Madagascar (99.3\% identity, [28]). Polychromophilus murinus sequences from bat flies were similar (92.4-98.7\% identity) to samples collected from vespertilionid bats in Switzerland (see also Figure 3).

Polychromophilus melanipherus showed high haplotype diversity both in bats and their ectoparasites. Two genetically different haplotypes were identified in the two bat fly species collected from bent-winged bats, while I. simplex ticks also provided different haplotypes. Unfortunately, our method prevented us from evaluating the true diversity of Polychromophilus spp. haplotypes in individuals sampled (both bats and/or ectoparasite individuals), as the method deployed (nested PCR) amplified only a single sequence from each sample. The six haplogroups identified clustered into two main groups, including all ectoparasite-derived and bat-derived sequences. While all Po. melanipherus-positive bats and ectoparasites were collected at a single site (Canaraua Fetii), this site hosts a huge maternity cluster of Mi. schreibersii, with up to 8000 individuals in summer [42,43], but no bats present in winter. Local recapture of ringed bats suggests multiple wintering areas for these bats, with hibernacula known in the NE, E, SE and SW ([44] and Barti L. unpublished). These subpopulations may host different genetic lineages of Po. melanipherus, all of which may be encountered at the maternity roost at Canaraua Fetii.

The high diversity of individual Polychromophilus spp. sequences encountered in bats, ticks, and bat flies (see Figure 2) suggest an intricate web of malaria-like parasite circulation among bats and their ectoparasites in eastern Europe, with multiple genotypes present even at the site level. This is likely the result of (i) either the adaptation of individual genotypes to specific vector or host species (in the case of the multi-host Po. murinus) or (ii) the presence of multiple genetic lineages of Po. melanipherus linked to different migratory subpopulations of bent-winged bats.

DNA of both haemosporidian species was identified in a polyxenous bat fly species, $P e$. dufourii, thus suggesting vector competence for both Polychromophilus species. This dipteran species commonly occurs on a number of cave-dwelling bat species like Mi. schreibersii, My. blythii, My. daubentonii or My. myotis [41], i.e., bat species of which populations may share the same underground roost (like in our case, the Canaraua Fetii site). At such roosts, individual bat flies may easily move not only between host individuals of the same species but also between different host species [45-47]. Thus, these flies have the potential to transfer both haemosporidian species to nonspecific bat hosts (e.g., Po. melanipherus to vesper bats and/or Po. murinus to Mi. schreibersii), too. The fact that we found no sign of such cross-infection in any of the host species may be an indication that there is a specific barrier of infectivity at the host level, an idea already suggested for Po. melanipherus [28].

\section{Conclusions}

Our results expanded the known geographical range of bat-associated Plasmodiidae species occurring in the Western Palearctic, showing wide distribution among bats and their ectoparasites in SE Europe. Here we report the first records of Polychromophilus murinus in three new bat species and Polychromophilus spp. in two tick and three bat fly species, thus increasing both host and possible vector species spectra. High genetic diversity is reported for both Polychromophilus species, with diverse genetic variants present even at the same location, suggesting that simultaneous presence of diverse host and vector assemblages may enhance malaria-like parasite diversity, too.

Supplementary Materials: The following are available online at https:/ / www.mdpi.com/2076-260 7/9/2/230/s1. Table S1: List of bat and ectoparasite species recorded to be harboring Polychromophilus spp., with geographical location and species of Plasmodiidae hosted. 
Author Contributions: A.D.S., A.C. and Á.P. initiated the study, participated in the sample collection and wrote the manuscript. L.B. and I.C. participated in the sample collection and provided important samples to the study. S.H. contributed to sample collection and manuscript writing. Z.K. and J.K. performed the phylogenetic analyses. A.D.M. organized part of the sample collection and contributed to the study design and manuscript preparation. All authors have read and agreed to the published version of the manuscript.

Funding: This research was supported by NKFIH-132794 (to S.H. and A.D.S.) and PN-III-P1-1.1-PD2019-0390 (to A.C. and S.H.) grants, Á.P. was supported by the Collegium Talentum Programme of Hungary and by the NTP-NFTÖ-20 grant. While working on this project, A.D.S. was supported by the János Bolyai Research Scholarship of the Hungarian Academy of Science and the UNKP 19-4-ÁTE-10 New National Excellence Program of MIT.

Institutional Review Board Statement: Permission for bat capture was provided by the Underground Heritage Commission (Romania) and the Bulgarian Ministry of Environment and Water (permit no. 718/24.08.2017). Bat banding license numbers are $24 / 2017$ and $111 / 2018$. Bats were handled according to the current law of animal welfare regulation (L206/2004), and the Research Bioethics Commission of USAMV CN approved the used methodology of bat handling. Permission from the Institutional Animal Care and Use Committee (IACUC) was not necessary because bats were released in the field after tick removal (none taken to participating Institutes).

Informed Consent Statement: Not applicable.

Data Availability Statement: All data are contained within the article and the supplementary material.

Acknowledgments: The authors would like to thank C. Aftene, D. Bălășoiu, C. Jére, S. Măntoiu, B. Sándor, A. Telea and T. Ursache for their contributions to fieldwork and T. Szentiványi for valuable help in laboratory analysis. Special thanks for research permits received from P.N. Portile de Fier, Forestry Service Baneasa and Environmental Protection Agency Salaj. Special thanks to Oriol Massana and Adrià López-Baucells for letting us use their photo as an insert in Figure 3.

Conflicts of Interest: The authors declare no conflict of interest. The funders had no role in the design of the study; in the collection, analyses, or interpretation of data; in the writing of the manuscript, or in the decision to publish the results.

\section{References}

1. WHO. World Malaria Report 2019; WHO: Geneva, Switzerland, 2019; ISBN 9789241565721.

2. Wyatt, K.B.; Campos, P.F.; Gilbert, M.T.P.; Kolokotronis, S.O.; Hynes, W.H.; DeSalle, R.; Daszak, P.; MacPhee, R.D.E.; Greenwood, A.D. Historical mammal extinction on Christmas Island (Indian Ocean) correlates with introduced infectious disease. PLoS ONE 2008, 3. [CrossRef] [PubMed]

3. Atkinson, C.T.; Thomas, N.J.; Hunter, D.B. Parasitic Diseases of Wild Birds; John Wiley \& Sons: London, UK, 2009 ; ISBN 0813804574.

4. Dadam, D.; Robinson, R.A.; Clements, A.; Peach, W.J.; Bennett, M.; Rowcliffe, J.M.; Cunningham, A.A. Avian malaria-mediated population decline of a widespread iconic bird species. R. Soc. Open Sci. 2019, 6, 182197. [CrossRef] [PubMed]

5. Ricklefs, R.E.; Fallon, S.M.; Bermingham, E. Evolutionary relationships, cospeciation, and host switching in avian malaria parasites. Syst. Biol. 2004, 53, 111-119. [CrossRef] [PubMed]

6. Duval, L.; Robert, V.; Csorba, G.; Hassanin, A.; Randrianarivelojosia, M.; Walston, J.; Nhim, T.; Goodman, S.M.; Ariey, F. Multiple host-switching of Haemosporidia parasites in bats. Malar. J. 2007. [CrossRef]

7. Rich, S.M.; Leendertz, F.H.; Xu, G.; LeBreton, M.; Djoko, C.F.; Aminake, M.N.; Takang, E.E.; Diffo, J.L.D.; Pike, B.L.; Rosenthal, B.M. The origin of malignant malaria. Proc. Natl. Acad. Sci. USA 2009, 106, 14902-14907. [CrossRef]

8. Lutz, H.L.; Patterson, B.D.; Kerbis Peterhans, J.C.; Stanley, W.T.; Webala, P.W.; Gnoske, T.P.; Hackett, S.J.; Stanhope, M.J. Diverse sampling of East African haemosporidians reveals chiropteran origin of malaria parasites in primates and rodents. Mol. Phylogenet. Evol. 2016, 99, 7-15. [CrossRef]

9. Borner, J.; Pick, C.; Thiede, J.; Kolawole, O.M.; Kingsley, M.T.; Schulze, J.; Cottontail, V.M.; Wellinghausen, N.; Schmidt-Chanasit, J.; Bruchhaus, I. Phylogeny of haemosporidian blood parasites revealed by a multi-gene approach. Mol. Phylogenet. Evol. 2016, 94, 221-231. [CrossRef]

10. Galen, S.C.; Borner, J.; Martinsen, E.S.; Schaer, J.; Austin, C.C.; West, C.J.; Perkins, S.L. The polyphyly of Plasmodium: Comprehensive phylogenetic analyses of the malaria parasites (order Haemosporida) reveal widespread taxonomic conflict. R. Soc. Open Sci. 2018, 5, 171780. [CrossRef]

11. Chellapandi, P.; Prathiviraj, R.; Prisilla, A. Molecular evolution and functional divergence of IspD homologs in malarial parasites. Infect. Genet. Evol. 2018, 65, 340-349. [CrossRef] 
12. Plowright, R.K.; Eby, P.; Hudson, P.J.; Smith, I.L.; Westcott, D.; Bryden, W.L.; Middleton, D.; Reid, P.A.; McFarlane, R.A.; Martin, G.; et al. Ecological dynamics of emerging bat virus spillover. Proc. R. Soc. B Biol. Sci. 2015, 282, 20142124. [CrossRef]

13. Mühldorfer, K. Bats and Bacterial Pathogens: A Review. Zoonoses Public Health 2013, 60, 93-103. [CrossRef] [PubMed]

14. Cabral, A.D.; Gama, A.R.; Sodré, M.M.; Savani, E.S.M.M.; Galvão-Dias, M.A.; Jordão, L.R.; Maeda, M.M.; Yai, L.E.O.; Gennari, S.M.; Pena, H.F.J. First isolation and genotyping of Toxoplasma gondii from bats (Mammalia: Chiroptera). Vet. Parasitol. 2013. [CrossRef] [PubMed]

15. Hornok, S.; Estók, P.; Kováts, D.; Flaisz, B.; Takács, N.; Szoke, K.; Krawczyk, A.; Kontschán, J.; Gyuranecz, M.; Fedák, A.; et al. Screening of bat faeces for arthropod-borne apicomplexan protozoa: Babesia canis and Besnoitia besnoiti-like sequences from Chiroptera. Parasites Vectors 2015. [CrossRef] [PubMed]

16. Molyneux, D.H.; Badfort, J.M. Observations on the Trypanosome of Pipistrellus pipistrellus in Britain, Trypanosoma (Schiszotrypanum) vespertilionis. Ann. Soc. Belg. Med. Trop. (1920) 1971, 51, 335-348.

17. Garnham, P.C. Types of bat malaria. Riv. Malariol. 1953, 32, 149-154. [PubMed]

18. Schaer, J.; Perkins, S.L.; Decher, J.; Leendertz, F.H.; Fahr, J.; Weber, N.; Matuschewski, K. High diversity of West African bat malaria parasites and a tight link with rodent Plasmodium taxa. Proc. Natl. Acad. Sci. USA 2013. [CrossRef]

19. Witsenburg, F.; Salamin, N.; Christe, P. The evolutionary host switches of Polychromophilus: A multi-gene phylogeny of the bat malaria genus suggests a second invasion of mammals by a haemosporidian parasite. Malar. J. 2012, 11, 1-9. [CrossRef]

20. Witsenburg, F.; Schneider, F.; Christe, P. Epidemiological traits of the malaria-like parasite Polychromophilus murinus in the Daubenton's bat Myotis daubentonii. Parasites Vectors 2014, 7, 1-8. [CrossRef]

21. Holz, P.H.; Lumsden, L.F.; Legione, A.R.; Hufschmid, J. Polychromophilus melanipherus and haemoplasma infections not associated with clinical signs in southern bent-winged bats (Miniopterus orianae bassanii) and eastern bent-winged bats (Miniopterus orianae oceanensis). Int. J. Parasitol. Parasites Wildl. 2019, 8, 10-18. [CrossRef]

22. Perkins, S.L.; Schaer, J. A modern menagerie of mammalian malaria. Trends Parasitol. 2016, 32, 772-782. [CrossRef]

23. Megali, A.; Yannic, G.; Christe, P. Disease in the dark: Molecular characterization of Polychromophilus murinus in temperate zone bats revealed a worldwide distribution of this malaria-like disease. Mol. Ecol. 2011, 20, 1039-1048. [CrossRef] [PubMed]

24. Gardner, R.A.; Molyneaux, D.H.; Stebbings, R.E. Studies on the prevalence of haematozoa of British bats. Mamm. Rev. 1987, 17, 75-80. [CrossRef]

25. Corradetti, A.; Verlini, F.; Almieri, C.; Neri, I.; Rostinolla, M. Studi su Polychromophilus melanipherus Dionisi, 1899, e su Polychromophilus murinus Dionisi, 1899. Parassitologia 1961, 3, 71.

26. Goedbloed, E.; Cremers-Hoyer, L.; Perié, N.M. Blood parasites of bats in the netherlands. Ann. Trop. Med. Parasitol. 1964, 58, 257-260. [CrossRef]

27. Gardner, R.A.; Molyneux, D.H. Polychromophilus murinus: A malarial parasite of bats: Life-history and ultrastructural studies. Parasitology 1988, 96, 591-605. [CrossRef]

28. Ramasindrazana, B.; Goodman, S.M.; Dsouli, N.; Gomard, Y.; Lagadec, E.; Randrianarivelojosia, M.; Dellagi, K.; Tortosa, P. Polychromophilus spp. (Haemosporida) in Malagasy bats: Host specificity and insights on invertebrate vectors. Malar. J. 2018, 17, 1-11. [CrossRef]

29. Dietz, C.; Kiefer, A. Bats of Britain and Europe; Bloomsbury Publishing: Lodon, UK, 2016; ISBN 9781472922021.

30. Theodor, O. An Illustrated Catalogue of the Rotchild Collection of Nycteribiidae in the British Museum; The British Museum: Lodon, UK, 1967.

31. Estrada-Peña, A.; Mihalca, A.D.; Petney, T. Ticks of Europe and North Africa: A Guide to Species Identification; Estrada-Peña, A., Mihalca, A.D., Petney, T., Eds.; Springer: Berlin/Heidelberg, Germany, 2018; ISBN 978-3-319-63760-0.

32. Sándor, A.D.; Corduneanu, A.; Péter, Á.; Mihalca, A.D.; Barti, L.; Csősz, I.; Szőke, K.; Hornok, S. Bats and ticks: Host selection and seasonality of bat-specialist ticks in eastern Europe. Parasit. Vectors 2019, 12, 1-10. [CrossRef]

33. Witsenburg, F.; Schneider, F.; Christe, P. Signs of a vector's adaptive choice: On the evasion of infectious hosts and parasite-induced mortality. Oikos 2015, 124, 668-676. [CrossRef]

34. Szentiványi, T.; Markotter, W.; Dietrich, M.; Clément, L.; Ançay, L.; Brun, L.; Genzoni, E.; Kearney, T.; Seamark, E.; Estók, P.; et al. Host conservation through their parasites: Molecular surveillance of vector-borne microorganisms in bats using ectoparasitic bat flies. Parasite 2020, 27. [CrossRef]

35. Dionisi, A. La malaria di alcune specie di pipistrelli. Atti della Soc. per gli Stud. della Malar. 1899, 1, $133-175$.

36. Garnham, P.C. Polychromophilus species in insectivorous bats. Trans. R. Soc. Trop. Med. Hyg. 1973, 67, 2-3. [CrossRef]

37. Landau, I.; Rosin, G.; Miltgen, F.; Hugot, J.; Leger, N.; Beveridge, I.; Baccam, D. Sur le genre Polycbromophilus-(Haemoproteidae, parasite de Microchiroptères). Ann. Parasitol. Hum. Comparée 1980, 55, 13-32. [CrossRef]

38. Ikeda, P.; Marinho Torres, J.; Perles, L.; Lourenço, E.C.; Herrera, H.M.; de Oliveira, C.E.; Zacarias Machado, R.; André, M.R. Intra-and Inter-Host Assessment of Bartonella Diversity with Focus on Non-Hematophagous Bats and Associated Ectoparasites from Brazil. Microorganisms 2020, 8, 1822. [CrossRef] [PubMed]

39. Cadenas, F.M.; Rais, O.; Humair, P.-F.; Douet, V.; Moret, J.; Gern, L. Identification of host bloodmeal source and Borrelia burgdorferi sensu lato in field-collected Ixodes ricinus ticks in Chaumont (Switzerland). J. Med. Entomol. 2007, 44, 1109-1117. [CrossRef]

40. Garnham, P.C.C. Malaria Parasites and Other Haemosporidia; Blackwell Scientific Publications Ltd.: Oxford, UK, 1966. 
41. Sándor, A.D.; Földvári, M.; Krawczyk, A.I.; Sprong, H.; Corduneanu, A.; Barti, L.; Görföl, T.; Estók, P.; Kováts, D.; Szekeres, S.; et al. Eco-epidemiology of Novel Bartonella Genotypes from Parasitic Flies of Insectivorous Bats. Microb. Ecol. 2018, 76, 1076-1088. [CrossRef]

42. Sándor, A.D.; Kontschán, J.; Plantard, O.; Péter, Á.; Hornok, S. Illustrated redescription of the male of Ixodes simplex Neumann, 1906. Ticks Tick. Borne. Dis. 2018, 9, 1328-1330. [CrossRef]

43. Péter, Á.; Barti, L.; Corduneanu, A.; Hornok, S.; Mihalca, A.D.; Sándor, A.D. First record of Ixodes simplex found on a human host, with a review of cases of human infestation by bat-specialist ticks. Preprint.

44. Benda, P.; Ivanova, T.; Horáček, I.; Hanák, V.; Červený, J.; Gaisler, J.; Gueorguieva, A.; Petrov, B.; Vohralík, V. Bats (Mammalia: Chiroptera) of the eastern Mediterranean. Part 3. Review of bat distribution in Bulgaria. Acta Soc. Zool. Bohemicae 2003, 67, 245-357.

45. Marshall, A.G. Ecology of insects ectoparasitic on bats. In Ecology of Bats; Springer: Boston, MA, USA, 1982; pp. 369-401, ISBN 978-94-009-5774-9.

46. Dick, C.W.; Dick, S.C. Effects of prior infestation on host choice of bat flies (Diptera: Streblidae). J. Med. Entomol. 2014, 43, 433-436.

47. McKee, C.D.; Krawczyk, A.I.; Sándor, A.D.; Görföl, T.; Földvári, M.; Földvári, G.; Dekeukeleire, D.; Haarsma, A.-J.; Kosoy, M.Y.; Webb, C.T. Host phylogeny, geographic overlap, and roost sharing shape parasite communities in European bats. Front. Ecol. Evol. 2019, 7, 69. [CrossRef] 